\title{
Removal of Copper Ions from Aqueous Solution by Bentonite Clay Applied in Soil in Leaching Columns
}

\author{
Gilvanise Alves Tito ${ }^{1}$, Lúcia Helena Garófalo Chaves ${ }^{1}$, Hugo Orlando Carvallo Guerra ${ }^{1}$, Josely Dantas Fernandes ${ }^{1}$ \\ \& Iêde de Brito Chaves ${ }^{1}$ \\ ${ }^{1}$ Department of Agricultural Engineering, Federal University of Campina Grande, Campina Grande, Paraiba \\ State, Brazil
}

Correspondence: Lúcia Helena Garófalo Chaves, Federal University of Campina Grande, Avenue Aprigio Veloso, 882, Campina Grande, CEP: 58429-140, Paraiba State, Brazil. Tel: 55-83-2101-1186. E-mail: lhgarofalo@hotmail.com

$\begin{array}{lcc}\text { Received: June 20, 2018 } & \text { Accepted: July 22, } 2018 & \text { Online Published: September 15, } 2018 \\ \text { doi:10.5539/jas.v10n10p360 } & \text { URL: https://doi.org/10.5539/jas.v10n10p360 }\end{array}$

The research is financed by Coordination of Improvement of Higher Level Personnel-CAPES (Brazil) and National Council for Scientific and Technological Development-CNPq (Brazil).

\begin{abstract}
The objective of this research was to evaluate the effect of bentonite applied in soil, on the removal of copper $(\mathrm{Cu})$ from aqueous solutions, in leaching columns. The experiment was carried out at laboratory using leaching columns filled with $4 \mathrm{~kg}$ of soil mixed with bentonite according to treatments $\mathrm{B} 0, \mathrm{~B} 30, \mathrm{~B} 60$ and $\mathrm{B} 90$, that is, 0; 30; 60 and $90 \mathrm{t} \mathrm{ha}^{-1}$ of bentonite. Each leaching column (experimental unit) was constituted of a PVC tube, with $0.10 \mathrm{~m}$ of diameter and $0.50 \mathrm{~m}$ height sectioned in two $0.20 \mathrm{~m}$ rings $(10-30 \mathrm{~cm}$ and $30-40 \mathrm{~cm})$ and one, on the top, of $0.10 \mathrm{~m}$ high, reserved for a hydraulic head of $0.08 \mathrm{~m}$. The columns were placed in a vertical support and saturated with distilled water by capillary ascension. Then percolation began, passing through the column five volumes of pores (initially four liters of water contaminated with $1000 \mathrm{mg}$ of $\mathrm{Cu}$ and afterwards one liter of distilled water). Ten leached aliquots of 0.5 volume of pores were collected and stored in polypropylene flasks in a refrigerator for quantification of copper $(\mathrm{Cu})$ by atomic absorption spectrophotometry. At the end of the tests, the solid material contained in each ring was collected and the $\mathrm{Cu}$ concentration determinated. Increasing doses of bentonite increased $\mathrm{Cu}$ retention in soil; $\mathrm{Cu}$ was more retained in the surface layer in all treatments; there was no copper leaching from the columns with 60 and $90 \mathrm{tha}^{-1}$ of bentonite application, indicating that all copper was retained in the soil avoiding thus potential risks for groundwater contamination.
\end{abstract}

Keywords: heavy metals; water reuse; adsorption; leaching

\section{Introduction}

Currently, pollution of water sources, whether surface or underground, is one of the major environmental problems affecting urban centers. Among the several sources of this pollution, the excessive use of fertilizers, pesticides and other chemical substances applied to the soil that can reach groundwater by leaching (Carmo et al., 2010). Effluents, mainly industrial wastewater containing lead, copper, cadmium and chromium and others metals can be a threat to ecosystems for example can contaminate groundwater resources and thus lead to a serious groundwater pollution problem. The dangers of contamination of water by heavy metals are not only restricted to the direct consumption of this contaminated water, but also the direct consequences in the food chain when it refers to bioaccumulative toxins. According to Oliveira and Marins (2011), heavy metals compromise environmental health because they are persistent, since they are not biodegradable, remaining long periods in the environment.

The higher or lower mobility of heavy metals is determined by soil attributes, such as clay content, $\mathrm{pH}$, cation exchange capacity, organic matter content and other factors influencing adsorption/desorption reactions, precipitation/dissolution, complexation and oxidation (Bertol et al., 2010) and percolation velocity (Costa, 2002). Due to the low mobility of the copper in the soil profile, which accentuates with increasing clay content, tends to 
accumulate it in the superficial layer (Gomes et al., 2001), having therefore, low leaching potential. However, excessive water applications (rain and/or irrigation) can cause subsurface losses (Sistani et al., 2008).

The reuse of treated effluents has great potential for agriculture, especially in arid and semi-arid regions of the Brazilian Northeast, where there is a lack of good quality water for irrigation, allowing this water to be destined to more noble uses (Dantas et al., 2014). Many physio-chemical methods have been proposed for removal of heavy metals from effluents, or else to reduce the mobility these metals. Among these, there is the adsorption process which is currently considered to be very suitable for wastewater treatment because of its simplicity and cost-effectiveness (Yadanaparthi et al., 2009; Kwon et al., 2010). According to Gottipati et al. (2012) and Banerjee et al. (2012) adsorption is a commonly used technique for the removal of metal ions from various effluents and/or for remediation of the contaminated effluents. Among widely used adsorbents for adsorption of metal ions include clay minerals (Veli \& Alyuz, 2007). Eloussaief and Benzina (2010), and Guerra and Airoldi (2008) evaluated the efficiency of clay-minerals in the removal of metallic cations present in effluents and soil, respectively. Natural materials or certain waste from industrial operation for example bentonite clay of inferior quality is one of the sources for low-cost adsorbents. Generally, these materials are easily available.

In the Paraíba State, there exists one of the most important Brazilian deposits of bentonite clays. This clay is predominantly composed of argilominerals of the group of smectite or montimorilonite and impurities of quartz. In some varieties are also kaolinite and illite (Menezes et al., 2009). Its 2:1 structure allows a greater capacity of water adsorption and ion exchange. Bentonite clay, being an anionic solid, has a remarkable affinity with metals, particularly heavy metals in solution (Bhattacharyya \& Gupta, 2008), for example, copper. This element especially adsorbed by clays due to their higher surface area and Fe/Mn/aluminum oxides contents (Acosta et al., 2009; Bi et al., 2013; Huang et al., 2014), moves slowly in the soil, usually as an organic complex, and remains on the surface of the soil (Paganini et al., 2004).

Considering the above, it is proposed in this work, to evaluate the effect of bentonite applied in soil, in the removal of copper $(\mathrm{Cu})$ from aqueous solutions, in leaching columns.

\section{Materials and Methods}

The study was conducted at the Irrigation and Salinity Laboratory of Federal University of Campina Grande located in Campina Grande, Paraiba State, using a Typic Quartzipisamment soil and bentonite clay. This soil, from the city of Lagoa Seca, Paraiba State, Brazil, was collected in the 0-20 cm deep layer, air dried, sieved through a $2.0 \mathrm{~mm}$ mesh sieved and chemically and physically characterized according to the methodology of Embrapa (2011) with the following results: $\mathrm{pH}\left(\mathrm{H}_{2} \mathrm{O}\right)=5.0 ; \mathrm{Ca}=0.51 \mathrm{cmol}_{\mathrm{c}} \mathrm{kg}^{-1} ; \mathrm{Mg}=0.20 \mathrm{cmol}_{\mathrm{c}} \mathrm{kg}^{-1} ; \mathrm{Na}=0.05 \mathrm{cmol}_{\mathrm{c}} \mathrm{kg}^{-1} ; \mathrm{K}$ $=0.18 \mathrm{cmol}_{\mathrm{c}} \mathrm{kg}^{-1} ; \mathrm{H}+\mathrm{Al}=0.56 \mathrm{cmol}_{\mathrm{c}} \mathrm{kg}^{-1} ; \mathrm{OM}=2.0 \mathrm{~g} \mathrm{~kg}^{-1} ; \mathrm{P}=5.4 \mathrm{mg} \mathrm{kg}^{-1} ; \mathrm{Cu}=6.05 \mathrm{mg} \mathrm{kg}^{-1} ;$ sand $=845.6 \mathrm{~g}$ $\mathrm{kg}^{-1} ;$ silt $=47.2 \mathrm{~g} \mathrm{~kg}^{-1}$; clay $=107.2 \mathrm{~g} \mathrm{~kg}^{-1}$.

The bentonite clay was collected at the Primavera deposit located in the Boa Vista County, Paraíba State. The bentonite samples analyzed through the X-ray fluorescence, using the EDX 720 equipment had the following constituents: $\mathrm{SiO}_{2}=76.784 \% ; \mathrm{Al}_{2} \mathrm{O}_{3}=13.339 \% ; \mathrm{Fe}_{2} \mathrm{O}_{3}=6.347 \% ; \mathrm{MgO}=2.225 \% ; \mathrm{CaO}=0.759 \%$; other oxides $=0.545 \%$. According to the X-ray diffractogram of bentonite, the characteristic peaks are of smectite or montmorillonite mineral clay, the main component of bentonite, tridimite peaks (it is a silicate mineral and a high temperature quartz polymorph), as well as the presence of a lesser amount of quartz. The cation exchange capacity $(48 \mathrm{meq} / 100 \mathrm{~g})$ and the specific area $\left(375 \mathrm{~m}^{2} / \mathrm{g}\right)$ of the bentonite were determined by the methylene blue method (Ferreira et al., 1972).

A completely randomized test with four doses of bentonite, $0 ; 30 ; 60$ and $90 \mathrm{t} \mathrm{ha}^{-1}$, and three replications was established totaling 12 experimental units. The soil column experimental unit, constructed in PVC with a diameter of $0.10 \mathrm{~m}$ and $0.50 \mathrm{~m}$ height was constituted by two $0.20 \mathrm{~m}$ rings and one $0.10 \mathrm{~m}$ superior ring, were overlaid and joined with silicone glue. To allow water percolation, at the bottom of the column was placed a PVC cap with a drain on its center. On the cap was placed a nylon fabric grid to support the solid material.

The soil and the doses of bentonite $(0 ; 0.45 ; 0.90$ and $1.35 \mathrm{~kg})$ denoted by B0; B30; B60 and B90, respectively, were mixtured and incubated for 30 days allowing a probable reaction between them. After this period, each column was filled with $4 \mathrm{~kg}$ of this mixture leaving at the top of column, an space of $0.10 \mathrm{~m}$ to maintain an hydraulic head of $0.08 \mathrm{~m}$.

The columns were placed in vertical support and saturated with distilled water by capillary ascension. Then the Mariotte bottle containing water contaminated with $250 \mathrm{mg} \mathrm{L}^{-1}$ of $\mathrm{Cu}\left(\mathrm{CuSO}_{4} \cdot 5 \mathrm{H}_{2} \mathrm{O}\right)$ was connected. Keeping a constant water depth of $0.08 \mathrm{~m}$, percolation began, passing through the columns five volumes of pores (one liter 
of distilled and four liters of water contaminated $(1000 \mathrm{mg}$ of $\mathrm{Cu}))$. Ten leached aliquots of 0.5 volumes of pores were collected. The pore volume of each column was determined by Equation (1):

$$
P v=\pi r^{2} h(1-d s / d p)
$$

where, Pv: pore volume $\left(\mathrm{cm}^{3}\right)$; r: column radius $(\mathrm{cm})$; h: column height $(\mathrm{cm})$; ds: soil density; dp: density of the particles.

The leachates were collected in polypropylene flasks, previously washed in 5\% hydrochloric acid solution and distilled water to be decontaminated, and stored in a refrigerator until the quantification of copper $(\mathrm{Cu})$ by atomic absorption spectrophotometry.

At the end of the tests, the columns were undone by separating the rings that composed them. The solid material contained in each ring was air dried and sieved in a $2 \mathrm{~mm}$ mesh. Then it was determined the $\mathrm{Cu}$ concentration present in this material according to Embrapa (2011).

The experimental data was analyzed by ANOVA using $\mathrm{F}$ test at $5 \%$ of significance level. In case of significant effect, it was performed regressions analyses (linear and quadratic). All the analyses were performed using the statistical software SISVAR (Ferreira, 2011).

\section{Results and Discussion}

Based on the analysis of variance, it was verified that the copper retained in the soil was significantly influenced at the $\mathrm{p}<0.01$ level by the doses of bentonite, by the depths and by the interaction between these factors (Table $1)$.

Table 1. Summary of the analyses of variance for the copper amount retained in the soil in two depths (D1 and D2) of the leaching columns, with increasing bentonite doses

\begin{tabular}{lll}
\hline Source of Variation & DF & Mean Square \\
\cline { 2 - 3 } & & Soil \\
\hline Bentonite (B) & 3 & $1234.02^{* *}$ \\
Error & 6 & 143.25 \\
Depth (D) & 1 & $1979267.53^{* *}$ \\
B $\times$ D & 3 & $134429.60^{* *}$ \\
Error & 10 & 437.79 \\
$B \times D 1$ & & \\
Linear Regression & 1 & $304707.76^{* *}$ \\
Quadratic Regression & 1 & $32468.80^{* *}$ \\
Deviation & 1 & $4671.07^{* *}$ \\
Error & 10 & 437.79 \\
\hline$B \times D 2$ & & \\
Linear Regression & 1 & $83731.23^{* *}$ \\
Quadratic Regression & 1 & $12701.01^{* *}$ \\
Deviation & 1 & $2044.00^{\mathrm{ns}}$ \\
Error & 10 & 437.79 \\
\hline CV1(\%) & & 2.56 \\
CV2(\%) & & 4.47 \\
Mean (mg) & & 468.37 \\
\hline (p & & \\
\hline
\end{tabular}

Note. $\left({ }^{* *}\right),\left({ }^{*}\right),\left({ }^{n-5}\right):(\mathrm{p} \leq 0.01)$ and $(\mathrm{p} \leq 0.05)$ and not significant, respectively. $\mathrm{DF}=$ Degree of Freedom. $\mathrm{CV}=$ Coefficient of Variation.

The largest amounts of copper were adsorbed in the soil superficial layer $(0-20 \mathrm{~cm})$ of the leaching column; the behavior of the adsorption of this element varied according to the increasing doses of bentonite applied to the soil adjusting to the quadratic model.

Comparing the amount of $\mathrm{Cu}$ retained in the soil with the highest bentonite dose $\left(90 \mathrm{t} \mathrm{ha}^{-1}\right), 917.43 \mathrm{mg}$, in relation to the control $\left(0 \mathrm{t} \mathrm{ha}^{-1}\right) 489.68 \mathrm{mg}$, there was an increase of $87.35 \%$ showing the beneficial effect of 
bentonite on the adsorption of this metal. This may be related to the cation exchange capacity of the bentonite clay, in whose negative electrical charges the metals are adsorbed. According to Acosta et al. (2009), Bi et al. (2013), and Huang et al. (2014) this is due to the higher specific surface area of the bentonites and $\mathrm{Fe} / \mathrm{Mn} /$ aluminum oxides, characteristic of the same. According to Kemerich et al. (2013), the elements $\mathrm{Zn}, \mathrm{Cu}$, $\mathrm{Cd}$ and $\mathrm{Pb}$ have a high affinity for the colloidal fraction of the soil and clays, forming, with the reactive surfaces of the clay, stable molecules that correspond to the specific adsorption, with high binding energy and stability.

Although the bentonite was homogeneously incorporated into the soil column, it was observed that in all treatments most of the $\mathrm{Cu}$ was retained in the superficial layer (Figure 1), confirming its low mobility, which is in agreement with Paganini et al. (2004). Bertol et al. (2010), evaluating the mobility of $\mathrm{P}, \mathrm{Cu}$ and $\mathrm{Zn}$ in soil columns, also observed that $\mathrm{Cu}$ was retained in the first layer of soil.

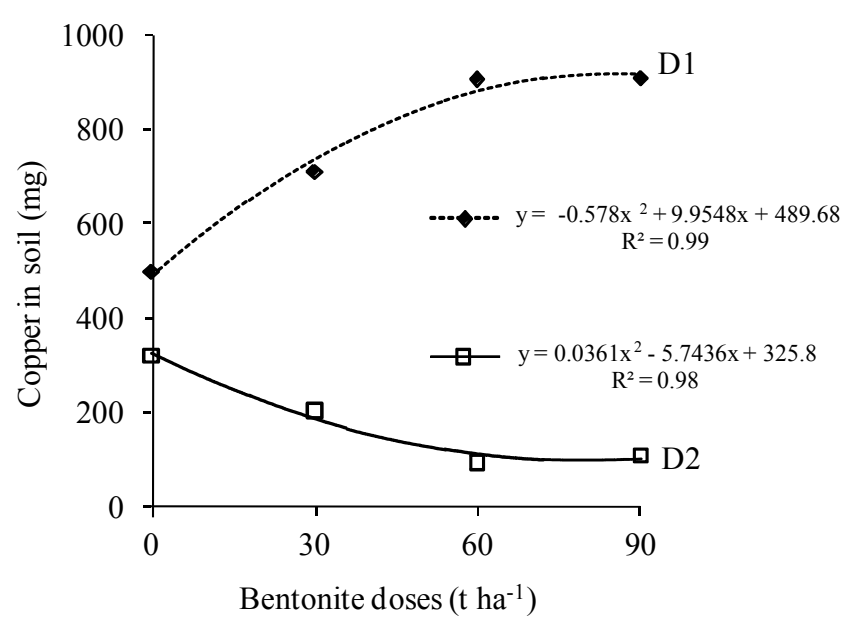

Figure 1. Copper amount retained in soil at depths D1 and D2 $(0-20 ; 20-40 \mathrm{~cm})$ of the leaching columns

Based on the analysis of variance (Table 2), it was verified that copper in the leachate was significantly influenced at the $\mathrm{p}<0.01$ level by the doses of bentonite, and that the data was fitted to a quadratic model (Figure 2).

Table 2. Summary of the analyses of variance for the copper in the leachate with increasing doses of bentonite

\begin{tabular}{lll}
\hline Source of Variation & DF & Mean Square \\
\cline { 2 - 3 } & & Leachate \\
\hline Bentonite (B) & 3 & $42721.83^{* *}$ \\
Linear Regression & 1 & $27658.94^{* *}$ \\
Quadratic Regression & 1 & $13068.66^{* *}$ \\
Deviation & 1 & $1994.22^{* *}$ \\
Error & 8 & 103.93 \\
\hline CV $(\%)$ & & 27.42 \\
Mean $(\mathrm{mg})$ & 37.18 \\
\hline
\end{tabular}

Note. $\left(^{* *}\right),\left({ }^{*}\right),\left(\overline{\left.{ }^{\mathrm{s}}\right)}\right):(\mathrm{p} \leq 0.01)$ and $(\mathrm{p} \leq 0.05)$ and not significant respectively. $\mathrm{DF}=$ Degree of Freedom. $\mathrm{CV}=$ Coefficient of Variation.

After the application of water contaminated with $250 \mathrm{mg} \mathrm{L}^{-1}$ of $\mathrm{Cu}$ in the columns, copper was only found in the leachates of columns filled with soil without bentonite (B0) and with B30 (30 t ha $\left.{ }^{-1}\right) 140.3$ and $8.3 \mathrm{mg}$, respectively. Copper was more leached in the soil without bentonite due to the presence of pores with larger diameters facilitating the percolation of the water together with the copper. The incorporation of the bentonite clay provides an increase of micropores and consequently reduces the percolation of the water facilitating the retention of the metal (Figure 2). In the case of the $\mathrm{B} 30$ treatment, the $30 \mathrm{tha}^{-1}$ of bentonite was not sufficient to 
adsorb all copper $\left(1000 \mathrm{mg} \mathrm{L}^{-1}\right)$ from the water applied to the columns. This shows that the amount of $\mathrm{Cu}$ present in this water was above the adsorption capacity of the bentonite at this dose $\left(30 \mathrm{tha}^{-1}\right)$. However, with the 60 and $90 \mathrm{t} \mathrm{ha}^{-1}$ dose of bentonite, there was an increase in the number of exchange sites available for the bonds between metal and clay, thus favoring the adsorption of $\mathrm{Cu}$; consequently, copper was not found in the leachate from columns with B60 and B90 treatments.

The high specific surface $\left(375 \mathrm{~m}^{2} \mathrm{~g}^{-1}\right)$ of this $2: 1$ clay favored the adsorption of the metal in the clay, corroborating Huang et al. (2014). According to these authors, fine soil aggregates and clay minerals have a greater capacity to retain heavy metals because of their larger surface area.

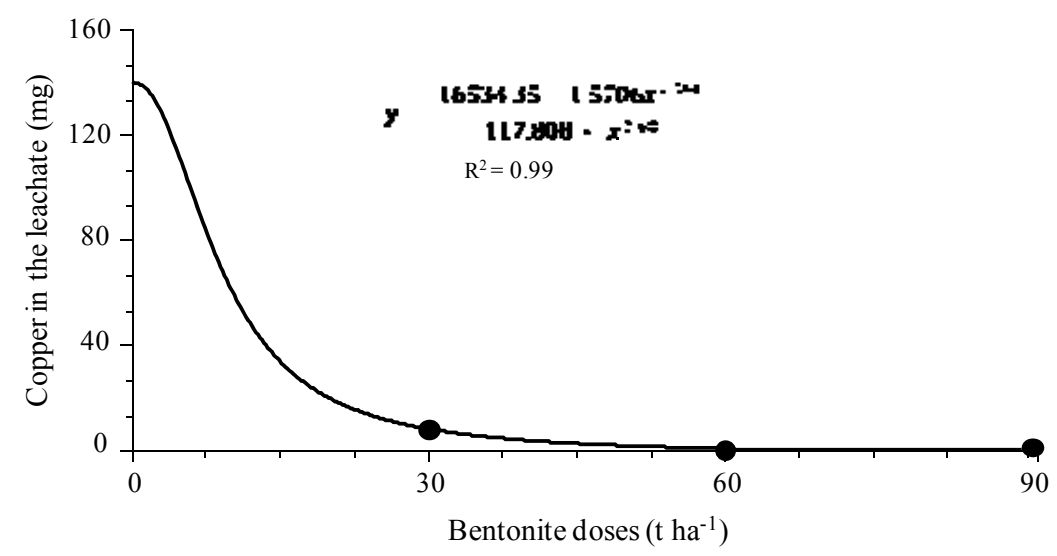

Figure 2. Amount of copper found in leachates as a function of increasing bentonite doses

Considering the amount of copper applied to the soil columns through the contaminated water $(1000 \mathrm{mg})$ plus the amount of this element already existing in the soil $(24.2 \mathrm{mg})$, totalizing $1024.2 \mathrm{mg}$ of $\mathrm{Cu}$, the percentages of copper remaining in the soil columns (two depths) and in the leachate were obtained. It was observed that most of the metal was retained in the soil, mainly in the superficial layer (depth of $0-20 \mathrm{~cm}$, D1), that is, $489.7 ; 736.3$; 878.9 and $917.4 \mathrm{mg}$ of $\mathrm{Cu}$, for the $0 ; 30 ; 60$ and $90 \mathrm{tha}^{-1}$ of bentonite, respectively. The application of 30, 60 and $90 \mathrm{t} \mathrm{ha}^{-1}$ of bentonite promoted an increase of 50.4; 79.5 and $87.3 \%$, respectively, when comparing with the control, 0 t ha $^{-1}$ (Figure 3).

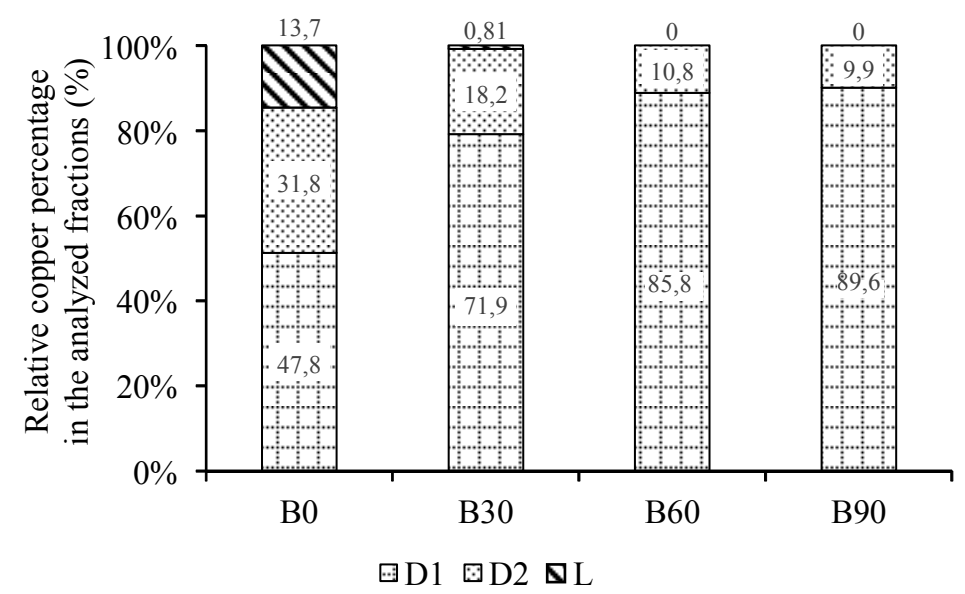

Figure 3. Copper percentage found in the three fraction analyzed (soil at two depths, D1 $(0-20 \mathrm{~cm})$ and D2 $(20-40 \mathrm{~cm})$ and in the leachate, $\mathrm{L})$ as a function of the doses of bentonite, B0, B30, B60, B90

The amount of $\mathrm{Cu}$ retained in the soil in the $20-40 \mathrm{~cm}$ layer (D2) decreased as a function of the increasing doses of bentonite, that is, 325.8; 185.9; 111.1 and $101.3 \mathrm{mg}$ corresponding to treatments B0, B30, B60 and B90, respectively, since the largest amount of copper had already been adsorbed in the superficial layer (D1). This 
promoted a decrease of $42.9 ; 65.9$ and $68.9 \%$, comparing the doses of 30,60 and $90 \mathrm{tha}^{-1}$ of bentonite with the control, $0 \mathrm{t} \mathrm{ha}^{-1}$ (Figure 3). It can be verified that the percentages of copper adsorbed to the soil at both depths were similar between the doses of 60 and $90 \mathrm{tha}^{-1}$.

I was observed in the leachates, $140.35 ; 8.35 ; 0$ and $0 \mathrm{mg}$ of copper when applied the doses of $0 ; 30 ; 60$ and $90 \mathrm{t}$ $\mathrm{ha}^{-1}$, of bentonite in the columns, corresponding, respectively, to $13.7 ; 0.8 ; 0$ and $0 \%$. There was no copper leaching from the soil columns with 60 and $90 \mathrm{tha}^{-1}$ of bentonite, indicating thus that all copper was retained in the soil (Figure 3).

\section{Conclusions}

The application of betonite to the soil increased the removal of copper from aqueous solutions through these leaching columns

Most of the copper retention occurred in the surface layer of the leaching columns

Doses of bentonite greater than $60 \mathrm{t} \mathrm{ha}^{-1}$, applied to the soil, could avoid potential risks of groundwater contamination in soils contaminated with $250 \mathrm{mg} \mathrm{L}^{-1}$ of $\mathrm{Cu}$.

\section{Acknowledgements}

Special thanks to the Coordination of Improvement of Higher Level Personnel—CAPES (Brazil) and National Council for Scientific and Technological Development - CNPq (Brazil) for the scholarship granted and financial support to the first author.

\section{References}

Acosta, J. A., Faz Cano, A., Arocena, J. M., Debela, F., \& Martinez-Martinez, S. (2009). Distribution of metals in soil particle size fractions and its implication to riskassessment of playgrounds in Murcia City (Spain). Geoderma, 149(1-2), 101-109. https://doi.org/10.1016/j.geoderma.2008.11.034

Banerjee, K., Ramesh, S. T., Nidheesh, P. V., \& Bharathi, K. S. (2012). A novel agricultural waste adsorbent, watermelon shell for the removal of copper from aqueous solutions. Iranica Journal of Energy and Environment, 3(2), 143-156. https://doi.org/10.5829/idosi.ijee.2012.03.02.0396

Bertol, O. J., Fey, E., Favaretto, N., Lavoranti, O. J., \& Rizzi, N. E. (2010). Mobilidade de P, Cu e Zn em colunas de solo sob sistema de semeadura direta submetido às adubações mineral e orgânica. Revista Brasileira de Ciência do Solo, 34(6), 1841-1850. https://doi.org/10.1590/S0100-06832010000600008

Bhattacharyya, K. G., \& Gupta, S. S. (2008). Influence of acid activationa on adsorption of Ni (II) and Cu(II) on kaolinite and montmorillonite: kinetic and thermodynamic study. Chemical Engineering Journal, 136(1), 1-13. https://doi.org/10.1016/j.cej.2007.03.005

Bi, X., Liang, S., \& Li, X. (2013). A novel in situ method for sampling urban soil dust:particle size distribution, trace metal concentrations, and stable lead isotopes. Environmental Pollution, 177, 48-57. https://doi.org/ 10.1016/j.envpol.2013.01.045

Carmo, A. I., Antonino, A. C. D., Netto, A. M., \& Corrêa, M. M. (2010). Caracterização hidrodispersiva de dois solos da região irrigada do Vale do São Francisco. Revista Brasileira de Engenharia Agrícola e Ambiental, 14(7), 698-704. https://doi.org/10.1590/S1415-43662010000700003

Costa, P. O. S. (2002). Avaliação em laboratório do transporte de contaminantes no solo do aterro sanitário de Sauípe/BA (p. 188, Dissertação, Mestrado em Engenharia Civil, PUC, Rio de Janeiro, Brazil).

Dantas, I. L. A., Faccioli, G. G., Mendonça, L. C., Nunes, T. P., Viegas, P. R. A., \& Santana, L. O. G. (2014). Viabilidade do uso de água residuária tratada na irrigação da cultura do rabanete (Raphanus sativus L.). Revista Ambiente e Água, 9(1), 109-117. https://doi.org/10.4136/ambi-agua.1220

Eloussaief, M., \& Benzina, M. (2010). Efficiency of natural and acid-activated clays in the removal of $\mathrm{Pb}(\mathrm{II})$ from aqueous solutions. Journal of Hazardous Materials, 178(1-3), 753-757. https://doi.org/10.1016/ j.jhazmat.2010.02.004

Embrapa, Centro Nacional de Pesquisa de Solos. (2011). Manual de métodos de analise de solo (2nd ed.). Embrapa, Rio de Janeiro.

Ferreira, D. F. (2011). Sisvar: A computer statistical analysis system. Ciência e Agrotecnologia, 35(6), 1039-1042. https://doi.org/10.1590/S1413-70542011000600001 
Ferreira, H. C., Chen, T., Zandonadi, A. R., \& Souza Santos, P. (1972). Correlações Lineares entre Áreas Específicas de Caulins Determinadas por Diversos Métodos-Aplicação a Alguns Caulins do Nordeste Brasileiro (Estados da Paraíba e Rio Grande do Norte). Cerâmica, 18(71), 333.

Gomes, P. C., Fontes, M. P. F., Silva, G., Mendonça, E. S., André, R., \& Netto, A. R. (2001). Selectivity sequence and competitive adsorption of heavy metals by Brazilian soils. Soil Science Society of American Journal, 65(4), 1115-1121. https://doi.org/10.2136/sssaj2001.6541115x

Gottipati, R., \& Susmita, M. (2012). Application of response surface methodology for optimization of Cr(III) and $\mathrm{Cr}(\mathrm{VI})$ adsorption on commercial activated carbons, Research Journal of Chemical Sciences, 2(2), 40-48.

Guerra, L. M., \& Airoldi, C. (2008). Anchores thiol smectite Clay-kinetic and thermodynamic studies of divalent copper and cobalt adsorption. Journal of Solid State Chemistry, 10, 6-9. https://doi.org/10.1016/j.jssc.2008. 06.028

Huang, B., Li, Z., Huang, J., Guo, L., Nie, X., Wang, Y., Zhang, Y., \& Zeng, G. (2014). Adsorption characteristics of $\mathrm{Cu}$ and $\mathrm{Zn}$ onto various size fractions of aggregates from red paddy soil. Journal of Hazardous Materials, 264, 176-183. https://doi.org/10.1016/j.jhazmat.2013.10.074

Kemerich, P. D. C., Mendes, S. A., Vorpagel, T. H., \& Piovesan, M. (2013). Impactos ambientais decorrentes da disposição inadequada de lixo eletrônico no solo. Engenharia Ambiental, 10(2), 208-219.

Kwon, J. S., Yun, S. T., Lee, J. H., Kim, S. O., \& Jo, H. Y. (2010). Removal of divalent heavy metals (Cd, Cu, Pb, and $\mathrm{Zn}$ ) and arsenic (III) from aqueous solutions using scoria: kinetics and equilibrium of sorption. Journal of Hazardous Materials, 174, 307-313. https://doi.org/10.1016/j.jhazmat. 2009. 09.052

Menezes, R. R., Souto, P. M., Santana, L. N. L., Neves, G. A. R., Kiminami, H. G. A., \& Ferreira, H. C. (2009). Argilas bentoníticas de Cubati, Paraíba, Brasil: Caracterização física-mineralógica. Cerâmica, 55, 63-169. https://doi.org/10.1590/S0366-69132009000200008

Oliveira, R. C. B., \& Marins, R. V. (2011). Dinâmica de metais-traço em solo e ambiente sedimentar estuarino como um fator determinante no aporte desses contaminantes para o ambiente aquático: Revisão. Virtual Química, 3(2), 88-102. https://doi.org/10.5935/1984-6835.20110014

Paganini, W. S., Souza, A., \& Bocchiglieri, M. M. (2004). Avaliação do comportamento de metais pesados no tratamento de esgotos por disposição no solo. Engenharia Sanitária e Ambiental, 9(3), 225-239. https://doi.org/10.1590/S1413-41522004000300009

Sistani, K. R., Mclaughlin, M. R., \& Brink, G. E. (2008). Soil nutrient evaluation from swine effluent application to five forage-system practices. Nutrient Cycling Agroecosystems, 82, 265-271. https://doi.org/10.1007/ s10705-008-9188-9

Veli, S., \& Alyuz, B. (2007). Adsorption of copper and zinc from aqueous solutions by using natural clay. Journal of Hazardous Materials, 149(1), 226-233. https://doi.org/10.1016/j.jhazmat.2007.04.109

Yadanaparthi, S. K. R., Graybill, D., \& Wandruszka, R. (2009). Adsorbents for the removal of arsenic, cadmium, and lead from contaminated Waters. Journal of Hazardous Materials, 171, 1-15. https://doi.org/ 10.1016/j.jhazmat.2009.05.103

\section{Copyrights}

Copyright for this article is retained by the author (s), with first publication rights granted to the journal.

This is an open-access article distributed under the terms and conditions of the Creative Commons Attribution license (http://creativecommons.org/licenses/by/4.0/). 